\title{
Leiden Mutation and the Course of Severe Acute Pancreatitis
}

\author{
A. V. Ershov, V. T. Dolgikh, T. I. Dolgikh, S. V. Morozov, Yu. P. Orlov, A. B. Reis
}

Department of Pathophysiology with a Course of Clinical Pathophysiology,

Omsk Sate Medical Academy, Ministry of Health of the Russian Federation

Objective: to evaluate the impact of Leiden mutation on the course of severe acute pancreatitis. Subjects and methods. One hundred and twelve people were examined. Group 1 comprised 50 patients diagnosed with severe acute pancreatitis without coagulation factor $V$ (Leiden) mutation. Group 2 included 42 patients with severe acute pancreatitis who were found to have Leiden mutation. Acute pancreatitis was first diagnosed in both groups. Group 3 consisted of 20 apparently healthy individuals (a control group). The severity of the underlying disease was determined in accordance with the clinical and laboratory parameters recommended by the I. I. Dzhanelidze Saint Petersburg Research Institute of Emergence Care. Results. This investigation revealed an association of Leiden mutation with trends in the development of acute pancreatitis. Group 2 exhibited a more severe disease: large focal pancreatic necrosis was twice more common and infectious complica-

Correspondence to:

Dolgikh Vladimir T.

E-mail: prof_dolgih@mail.ru tions developed more frequently; more aggressive and radical treatments were more often used. The patients with Leiden mutation had higher mortality rates $(33 \%$ in the Leiden mutation group and $24 \%$ in the non-mutation group. 
Conclusion. The findings should be kept in mind in elaborating new diagnostic methods and principles in the treatment of the underlying disease and in the prevention of its complications in patients with severe acute pancreatitis. Key words: acute pancreatitis, Leiden mutation.

In recent years the incidence of acute pancreatitis has not undergone any dramatically changes [1]. On one hand this is due to peculiarities of eating habits with increasing consumption of alcohol and its surrogates, cholelithiasis prevalence all resulting in number of patients increased. On another hand, improvement in clinical, laboratory and instrumental diagnosis of the disease also contributed to constant occurance of the disease [2]. Mortality rate due to destructive forms of acute pancreatitis exceeded $20 \%$ both nationally and internationally [3]. Severe disorders of hemostasis in critical illness including acute pancreatitis are caused by many factors where destructive processes in organs and tissues, massive bleeding and transfusions, endotoxemia and hypoxia play a leading role $[4,5]$. Increase of blood hemoconcentration and viscosity in pancreatonecrosis cause hypercoagulation and thrombophilia, which significantly contribute to development of disseminated intravascular coagulation $[3,6]$. Genetic mutation of genes that control the folate circle and coagulation factors II and V significantly increase the risk of of primary and recurrent venous and arterial thrombosis even in apparently healthy individuals $[7,8]$. Only few research studies, however, were devoted to evaluation of pathogenetic significance of the hemostatic system gene alterations in acute pancreatitis. Thereupon, the objective of the present study was to evaluate a pathogenic effect of factor $\mathrm{V}$ Leiden mutation in severe acute pancreatitis.

\section{Materials and methods}

From total of 112 patients $72(64 \%)$ were men and 40 (36\%) women aged 21 to 53 years (mean age was $33,2 \pm 3,1$ years). 50 patients (34 men and 16 women) with severe acute pancreatitis without factor $\mathrm{V}$ Leiden mutation were included in the group I (a comparison group). The main group II ( $n=42)$ consisted of 33 men and 9 women diagnosed with severe acute pancreatitis and factor V Leiden mutation (40 patients were heterozygotes and 2 patients carried altered allele in a homozygous form). Acute pancreatitis was diagnosed in both groups for the first time. Patients in both groups received antibiotic, analgesic and detoxification (plasmapheresis and indirect electrochemical blood oxidation by means of sodium hypochlorite) therapy. 10 patients in the group I and 8 patients in the group II were performed «minor» drainage operations. During the observation period 12 lethal cases $(24 \%)$ were registered in the group I and 14 lethal cases (33\%) were recorded in the group II whereof 12 patients with the heterozygous mutation and 2 patients with the homozygous mutation.

The patients with acute pancreatitis diagnosed at the time of admission according to clinical and laboratory data, as well as ultrasonography, computerized tomography and laparoscopy results were included into the study. Infection of the necrotic zones and fluid parapancreatic formations were evaluated using clinical and bacteriological results. The primary disease severity was confirmed by the clinical and laboratory criteria (Table 1) recommended by I. I. Dzhanelidze St. Petersburg Emergency Care Research Institute [9]. The diagnosis of acute destructive pancreatitis in group I ( $60 \%$ cases) and in group II (69\% cases) was proved by means of laparoscopy within one day from the time of admission.

All patients were treated in the Intensive Care Units of the Surgery and Purulent Surgery Departments at the Municipal Clinical Emergency Hospital №1 and Omsk Clinical Medical and Surgical Center during the period from 2009 to 2013. The reasons caused acute pancreatitis included gallstone disease, alcohol abuse and diet violation (Table 2). The patients with chronic cardiopulmonary disorders in decompensation stage, chronic diseases of kidneys, pancreas, gastrointestinal tract and liver, as well as with cancer pathology, diabetes and obesity III-IV were excluded from the study. General condition severity evaluation of the patients in both groups was performed according to the scale APACHE II (Acute Physiology Age Chronic Health Evaluation). General condition severity in the group I as per the scale APACHE II was $22,9 \pm 2,2$ scores and 24,2 $\pm 2,3$ scores in the group II $(p>0.05)$.

The severity was assessed at the admission, after 24 hours from the beginning of intensive therapy, and on the $3^{\text {rd }}$ and $5^{\text {th }}$ day after hospitalization. Blood specimens for clinical, biochemical and molecular genetic laboratory testing were sampled at

Clinical criteria of severe acute pancreatitis

Table 1

Principal signs of severity of patient's condition
Mottled skin
Heart rate more than 120 or less than 70 in minute
Oligo-anuria
Hemorrhagic peritoneal exudate
Erythrocytes hemolysis
Decrease of lymphocytes absolute number, less than $0,7 \times 10^{9} / 1$

Additional signs for patient's state severity

Diagnosis «Acute abdomen»

Anxiety, excitement/apathy

Hyperemia of face

Cold sweat

Hb concentration more than $140 \mathrm{~g} / \mathrm{l}$

Leukocytosis more than $13 \times 10^{9} / 1$

Hyperglycemia more than $7 \mathrm{mmol} / \mathrm{l}$

Total bilirubin more than $21 \mathrm{mmol} / \mathrm{l}$

without any signs of cholelithiasis

Table 2

Distribution of patients with acute pancreatitis depending on etiology of the disease

\begin{tabular}{lccc}
\hline Etiological factor & \multicolumn{2}{c}{ Number of patients and severity of their general condition in groups } \\
\cline { 2 - 4 } & I & II & total \\
\hline Cholelithiasis, abs. (\%) & $25(50,0)$ & $22(52,4)$ & 47 \\
Alcohol abuse, abs. (\%) & $13(26,0)$ & $10(23,8)$ & 23 \\
Diet violation, abs. (\%) & $12(24,0)$ & $10(23,8)$ & 22 \\
Total & 50 & 42 & 92 \\
\hline
\end{tabular}


indicated time points. Toxicity indicators were determined by standardized methods, such as M. J. Malakhova's method for low and average molecular weight substances [12] and Lowry's method. Genetic mutations were detected by polymerase chain reaction.

During the study groups were compared according to final dynamic parameters of disease development, such as the pathology form and its complications, frequency of specific treatment modes application and their efficacy. Unfortunately clinical parameters of acute pancreatitis with and without factor $\mathrm{V}$ Leiden mutation havent been thoroughly clarified so far. Thus, proof of dependence of severity course, treatment efficacy, outcomes and acute pancreatitis complications on genetic alteration will allow us to work further toward deciphering the impact of genetic mutation on mechanisms of the disease development.

20 individuals, who were non-permanent and permanent blood donors (12 men, aged 31,4 $\pm 2,2$ years, and 8 women, aged $32,3 \pm 1,8$ years, both without somatic diseases) with no signs of any deasese, were included in the group III (healthy control). Blood samples were harvested at the Municipal Blood Transfusion Station in compliance with aseptic and antiseptic rules at the same day and established protocol.

Statistic data processing was conducted using the software Statistica 6.0 for Windows with the Mann-Whitney test to compare independent samples differences, and Student's t-test was used for normally distributed general populations. The normality of general population distribution was determined by Kolmogorov-Smirnov criteria. Checking of interrelation significance between two categorical variables was performed by using $\chi^{2}$. Statistical significanxce was determined at $P<0,05$.

\section{Results and discussion}

All patients with acute pancreatitis underwent either miniinvasive surgery such as laparoscopy or surgery with drainage of omental bursa and retroperitoneal space, sani- tation and drainage of the abdominal cavity, or conservative treatment taken into consideration the disease severity. 16 patients from the group I and 5 patients from the group II were treated conservatively (Table 3 ).

12 patients from the comparison group underwent abdominal surgery and 22 patients from the same group underwent 'minor' drainage operation. Due to efficacy and positive dynamics in primary disease the combination of active detoxification methods and vasopressor support for blood pressure in patients allowed to reduce a volume of surgical treatment in the group I, and completely abandon surgery in one third of cases. Major operative interventions were performed as often as twice more in patients from the group II (40.5\% versus $24 \%$ in group I). Prolonged mechanical ventilation was conducted in 11 cases in patients from the group I due to septic shock development.

Table 4 demonstrate that the development of macrofocal pancreatic necrosis in the main group was observed more frequently than in the comparison group. Apparently, this is due to the microvasculature elements dysfunction in destruction of the pancreas caused by a precapillary spasm against catecholamine excess, erythrocytes sludging and deceleration, stasis and local microthrombosis development [10]. It should be emphasized that all factors apart from local microthrombosis in reconstituted conditions must provide the identical effect in both groups. To our opinion, the gene mutation causes more extensive damages to the pancreas facilitating in concert with other factors development of thrombotic complications of the primary disease. Mechanistically, in the presence of Leiden mutation the factor $\mathrm{V}$ is not split by the natural anticoagulant

Various treatment modes application for patients with severe acute pancreatitis

Table 3

\begin{tabular}{|c|c|c|c|c|c|c|}
\hline \multirow[t]{2}{*}{$\overline{\text { Groups }}$} & \multicolumn{6}{|c|}{ Modes of conducted treatment, abs. (\%) } \\
\hline & $\begin{array}{c}\text { major surgical } \\
\text { treatment }\end{array}$ & $\begin{array}{c}\text { minor surgical } \\
\text { treatment }\end{array}$ & $\begin{array}{c}\text { artificial } \\
\text { pulmonary } \\
\text { ventilationt }\end{array}$ & $\begin{array}{c}\text { indirec } \\
\text { electrochemical } \\
\text { blood oxidation }\end{array}$ & $\begin{array}{c}\text { discrete } \\
\text { plasmapheresis }\end{array}$ & $\begin{array}{c}\text { vasopressor } \\
\text { support }\end{array}$ \\
\hline $\mathrm{I}(n=50)$ & $12(24,0)$ & $22(44,0)$ & $7(14,0)$ & $41(82,0)$ & $17(34,0)$ & $29(58,0)$ \\
\hline II $(n=42)$ & $17(40,5)^{*}$ & $20(47,6)$ & $11(26,2)^{*}$ & $11(26,2)^{*}$ & $9(21,4)$ & $10(23,8)^{*}$ \\
\hline
\end{tabular}

Note. Here and in tables 4 and $5:^{*}-P<0,05$ while comparison among groups.

Table 4

Clinical forms of acute pancreatitis in examined patients

\begin{tabular}{lccc}
\hline Clinical pancreatitis form & \multicolumn{2}{c}{ Number of patients and severity of their general condition in groups } \\
\cline { 2 - 3 } & I $(\boldsymbol{n}=\mathbf{5 0})$ & II $(\boldsymbol{n}=\mathbf{4 2})$ & total \\
\hline Microfocal pancreatonecrosis & $32(64,0 \%)$ & $20(47,6 \%)$ & 52 \\
Macrofocal pancreatonecrosis & $18(36,0 \%)$ & $22(52,4 \%)^{*}$ & 40 \\
Total & 50 & 42 & 92 \\
\hline
\end{tabular}

Table 5

Distribution of patients due to the form of destructive pancreatitis and its complications

\begin{tabular}{|c|c|c|c|}
\hline \multirow[t]{2}{*}{ Clinical pancreatitis form } & \multicolumn{3}{|c|}{ Number of patients and severity of their general condition in groups } \\
\hline & I $(n=50)$ & II $(n=42)$ & total \\
\hline Sterile pancreatonecrosis & $12(24,0 \%)$ & $5(11,9 \%)^{*}$ & $17(18,5 \%)$ \\
\hline Infected pancreatonecrosis including hemorrhagic pancreatonecrosis & $21(42,0 \%)$ & $16(38,1 \%)$ & $37(40,2 \%)$ \\
\hline Pancreatogenic sepsis & $17(34,0 \%)$ & $21(50,0 \%)^{*}$ & $38(41,3 \%)$ \\
\hline Total & 50 & 42 & 92 \\
\hline
\end{tabular}


Dynamic changes in patients with severe acute pancreatitis during endotoxemia

\begin{tabular}{|c|c|c|c|c|c|c|c|}
\hline \multirow[t]{3}{*}{ Indices } & \multicolumn{7}{|c|}{ Value of indicators $(M \pm \sigma)$ in the groups on the stages of the research, days } \\
\hline & \multicolumn{3}{|c|}{ I $(n=42)$} & \multicolumn{3}{|c|}{ II $(n=50)$} & \multirow[t]{2}{*}{ III $(n=25)$} \\
\hline & $1^{\mathrm{st}}$ & $3^{\text {rd }}$ & $5-6^{\text {th }}$ & $1^{\text {st }}$ & $3^{\text {rd }}$ & $5-6^{\text {th }}$ & \\
\hline Leukocytes, $10^{9} / 1$ & $18,8 \pm 3,1^{\#}$ & $19,4 \pm 2,0^{\#}$ & $14,4 \pm 1,8^{* *, \#}$ & $21,4 \pm 1,4^{*}, \#$ & $20,1 \pm 1,5^{\#}$ & $15,2 \pm 3,1^{* *}, \#$ & $5,9 \pm 2,1$ \\
\hline Stab neutrophils, $10^{9} / 1$ & $9,1 \pm 0,4^{\#}$ & $10,2 \pm 1,3^{\#}$ & $7,7 \pm 1,3^{* *, \#}$ & $16,2 \pm 0,9 *, \#$ & $16,8 \pm 1,1^{*, \#}$ & $18,8 \pm 1,6^{*}, \#$ & $0,5 \pm 0,05$ \\
\hline Lymphocytes, $10^{9} / 1$ & $8,3 \pm 2,0^{\#}$ & $7,8 \pm 1,6^{\#}$ & $11,6 \pm 1,6^{* *}$ & $7,7 \pm 1,0^{\#}$ & $6,3 \pm 0,9^{\#}$ & $2,2 \pm 0,8^{*, * *, \#}$ & $13,8 \pm 1,2$ \\
\hline $\begin{array}{l}\text { Substances of low } \\
\text { and average molecular weight } \\
\text { in erythrocytes, RVU }\end{array}$ & $33,3 \pm 4,1^{\#}$ & $34,1 \pm 2,2^{\#}$ & $22,1 \pm 4,1 * *, \#$ & $37,8 \pm 3,0^{\#}$ & $37,2 \pm 1,9^{\#}$ & $33,0 \pm 1,8^{*, * *, \#}$ & $18,7 \pm 0,33$ \\
\hline $\begin{array}{l}\text { Substances of low } \\
\text { and average molecular weight } \\
\text { in plasma, RVU }\end{array}$ & $16,1 \pm 1,10^{\#}$ & $25,3 \pm 2,8 * *, \#$ & $8,3 \pm 1,8 * *$ & $24,1 \pm 1,2^{\#}$ & $27,1 \pm 0,9^{\#}$ & $10,1 \pm 2,2^{* *, \#}$ & $6,9 \pm 0,15$ \\
\hline Oligopeptides & & & & & & & \\
\hline in plasma, $\mathrm{mg} / \mathrm{ml}$ & $0,18 \pm 0,01^{\#}$ & $0,18 \pm 0,01^{\#}$ & $0,14 \pm 0,01^{* *, \#}$ & $0,29 \pm 0,02^{*}, \#$ & $0,38 \pm 0,12^{*, \#}$ & $0,40 \pm 0,14^{*, \#}$ & $0,07 \pm 0,01$ \\
\hline index, RVU & $8,2 \pm 2,0^{\#}$ & $8,4 \pm 0,9^{\#}$ & $8,5 \pm 1,2^{\#}$ & $9,2 \pm 1,0^{\#}$ & $8,6 \pm 0,4^{\#}$ & $9,1 \pm 0,8^{\#}$ & $0,6 \pm 0,07$ \\
\hline
\end{tabular}

Note. ${ }^{*}-P<0,05$ while comparison among groups in identical periods of study; $* *-P<0,05$ while comparison inside of the group with a previous level; \# $-P<0,05$ while comparison among groups.

protein $\mathrm{C}$, as this occurs in the absence of the genetic alteration, but becomes resistant to its effect. Due to resistance to protein $\mathrm{C}$ clotting factor $\mathrm{V}$ concentration is increased becoming a provocative factor for thrombus formation in organs including the pancreas [10].

Development of microfocal pancreatonecrosis, a mild form of destructive pancreatitis, was detected by $25.6 \%$ more often in patients without Leiden mutation than in patients with this mutation.

Thus, despite the identical preventive measures for thromboembolism in each group (controlled hypocoagulation under heparin, 15 million IU/day subcutaneously, and pentoxifylline, $500 \mathrm{mg}$ /day), predominance of coagulation components in blood of the patients of the main group caused a secondary damage of the pancreas due to pancreas vessels microthrombosis and increase of necrosis foci, that, in turn, indirectly and / or directly activated the clotting system creating a vicious circle.

Table 5 shows that pancreatogenic sepsis was observed in patients in the groups I and II that was equal to $41.3 \%$ from the total number of patients and nearly $70 \%$ of patients were needed different surgical interventions.

Significant increase in infectious complications in patients with severe acute pancreatitis is stipulated by late medical care $\left(4-5^{\text {th }}\right.$ day after disease onset), severe violations of water-electrolyte metabolism and acid-base balance, hypovolemia, endotoxicosis, enteric microflora translocation under tissue hypoxia and acidosis against palsy and pancreas microvasculature dysfunction that has been confirmed by pathophysiological and clinical studies [11].

The maximum value of the leukocyte intoxication index was registered in patients of the group II which was higher 15.3-fold and 1.12-fold in control and comparison groups, respectively (Table 6). Changes in the study parameters indicated a growth of dramatic endotoxemia in patients to the $3^{\text {rd }}$ day of the intensive therapy. Moreover, a significant increase in a plasma toxicity due to accumulation of low and average molecular weight substances and oligopeptides was revealed. Maximum concentration of low and average molecular weight substances and oligopeptides in plasma and erythrocytes was detected in the group II.

The second stage of endotoxemia as determined by accumulation of low and average molecular weight substances both on erythrocytes and in plasma (in accordance to M. J. Malakhova method [12]) was observed in patients in the group I at the time of admission and during three days of treatment, The third stage of endotoxemia ( $\ll$ a complete saturation phase») or reversible compensation of the natural detoxification system clinically manifested by more severe endotoxemia induced apparently by increasing of catabolic processes was observed in patients of the group II at the time of admission. At the same period a large number of final and intermediate metabolism products in extraordinary high concentrations, various biologically active substances, products of cell destruction and active, out-of-control proteolysis of plasma proteins were detected in the blood. At this phase in dynamics the concentration of low and average molecular weight substances was progressively increased and remained unchanged or decreased in erythrocytes.

Worsening of endotoxemia severity in patients of the group II to 3-6 days was evidently associated with hypercoagulation due to a typical «shock» activation of the blood coagulation system and decrease of anticoagulation system activity as a result of Leiden mutation [13], as well as developing high intraperitoneal pressure due to enzymatic peritonitis and intestinal paresis resulted from ischemia and hypoxia of the intestinal wall tissues. This created favorable conditions for the intestinal microflora and toxins translocation into the bloodstream during reperfusion and corresponded in terms to purulent infection foci formation in the abdominal cavity [14].

It should be noted there were no any reliable distinctions in respect to the concentration level of the low and average molecular weight substances in the erythrocyte membranes and lymphocytes rate in the group I to the 5-6 days in comparison with the control group. At the same time, despite the positive dynamics a growth of 
stabbed neutrophils rate and oligopeptide concentration remained stable in the group II up to the end of the study.

Progressive severity of endotoxemia, central hemodynamics and microcirculation disorders, hypercoagulation and multiple organ failure caused the high death rate (24\%) among the patients in the group I, and an increased trend in the group II (33\%) even along with administration of the adequate antibiotic therapy $(p<0.05)$. Bacteriological examination of blood and urine revealed a high growth of both gram-positive (82\%) and gram-negative (10\%) microflora that included S.aureus including MRSA+, S.epidermidis, E.coli, K.pneumoniae. Similar findings have been described earlier [11, 15].

This study revealed significant differences in severe acute pancreatitis course in patients with and without factor V Leiden mutation. Apparently, the changes caused by the mutation lead to alteration within the pancreas in the hemostatic system facilitating the size increasing and appearance of new necrosis foci in the affected organ. Moreover, the intensive process of microthrombogenesis (as a result of disorders of microcirculation in shock, triggerring multiple activation mechanisms of the coagula-

References

1. Smelaya T.V., Salnikova L.E., Moroz V.V., Golubev A.M., Zarzhetsky Yu.V., Rubanovich A.V. Genetichesky polimorfizm i chastota razvitiya oslozhnenii pri pnevmonii razlichnogo genezisa. [Genetic polymorphism and the rate of development of complications in pneumonia of varying genesis]. Obshchaya Reanimatologiya. 2011; 7 (2): 10-16. [In Russ.]

2. Moroz V.V., Smelaya T.V., Golubev A.M., Salnikova L.E. Genetika i meditsina kriticheskikh sostoyanii: ot teorii k praktike. [Genetics and medicine of critical conditions: from theory to practice]. Obshchaya Reanimatologiya. 2012; 8 (4): 5-12. [In Russ.]

3. Tarasenko V.S., Kubyshkin V.A., Demin D.B., Volkov D.V., Smolyagin A.I., Chukina O.V. Immunologicheskie narusheniya pri pankreonekroze i ikh korrektsiya. [Immunological disorders in pancreatic necrosis and their correctio]. Khirurgiya. Zhurnal Imeni N.I.Pirogova. 2013; 1: 88-95. [In Russ.]

4. Bianchi M.E. DAMPs, PAMPs and alarmins: all we need to know about danger. J. Leukoc. Biol. 2007; 81 (1): 1-5. http://dx.doi.org/10.1189/ jlb.0306164. PMID: 17032697

5. Savelyev V.S., Filimonov M.I., Gelfand B.R. Ostryi pankreatit kak problema urgentnoi khirurgii i intensivnoi terapii. Intensivnaya terapiya v khirurgii. [Acute pancreatitis as a problem of urgent surgery and intensive therapy]. Consilium medicum. 2000; 2 (9): 16. [In Russ.]

6. Vinokurov M.M., Savelyev V.V., Khlebnyi E.S., Kershengolts B.M Kompleksnaya otsenka urovnya endogennoi intoksikatsii u bolnykh v sterilnoi faze pankreonekroza. [Integrated estimation of the level of endogenous intoxication in patients with sterile-phase pancreatic necrosis]. Khirurgiya. Zhurnal Imeni N.I.Pirogova. 2012; 10: 21-26. [In Russ.]

7. Moroz V.V., Golubev A.M., A fanasyev A.V., Kuzovlev A.N., Sergunova V.A. Gudkova O.E., Chernysh A.M. Stroenie i funktsiya eritrotsita v norme pri kriticheskikh sostoyaniyakh. [The structure and function of a red blood cell in health and critical conditions]. Obshchaya Reanimatologiya. 2012; 8 (1): 52-60. [In Russ.]

8. Filimonov M.I., Burnevich S.Z. Khirurgiya pankreonekroza: 80 lektsii po khirurgii. [Surgery for pancreatic necrosis: 80 lectures on surgery]. Moscow: Litterra; 2008. [In Russ.]

9. Doix S., Mahrousseh M., Jolak M., Laurent Y., Lorenzini J.L., Binquet C., Zeller M., Cottin Y., Wolf J.E. Factor V Leiden and myocardial infarction: a case, review of the literature with a meta-analysis. Ann. Cardiol. Angeiol. (Paris). 2003; 52 (3): 143-149. PMID: 12938565 tion system and because of reduced activity of a genetically altered anticoagulation system) affected not just a pancreas, but also caused the deterioration of a course of the disease.

\section{Conclusion}

Arguments and facts obtained during the study should be taken into consideration when developing novel diagnostic approaches, treatment strategies and methods of prevention of complications in patients with severe acute pancreatitis. The possibilities of mutation of genes affecting hemostasis should be considered when selecting the drugs, treatment option and strategies to prevent hemostatic complications. Molecular genetics diagnostic screening of hemostasis pathology is needed to optimize and personalize treatment of patients with severe acute pancreatitis and prevent or diminish its complications. This strategy seems to be more promising than the current paradigm utilizing similar approach to treatment independently on possibility of alteration(s) of gene(s) that control the pathogenesis of acute pancreatitis.

10. Folsom A.R., Cushman M., Tsai M.Y., Aleksic N., Heckbert S.R., Boland L.L., Tsai A.W., Yanez N.D., Rosamond W.D. A prospective study of venous thromboembolism in relation to factor $\mathrm{V}$ Leiden and related factors. Blood. 2002; 99 (8): 2720-2725. http://dx.doi.org/10.1182/ blood.V99.8.2720. PMID: 11929758

11. Tolstoi A.D., Goltsov R.V. Vozmozhnosti «obryva» destruktivnogo protsessa na rannikh stadiyakh pankreonekroza. [Possibilities of a «break» in the destructive process in early-stage pancreatic necrosis]. Obshchaya Reanimatologiya. 2005; 1 (3): 58-60. [In Russ.]

12. Sukach M.S., Dolgikh V.T. Vliyanie geptrala na koagulyatsionnuyu aktivnost krovi pri pankreonekroze. [Effect of heptral on blood coagulation activity in pancreonecrosis]. Obshchaya Reanimatologiya. 2011; 7 (6): 34-39. [In Russ.]

13. Savelyev V.S., Filimonov M.I., Gelfand B.R., Burnevich S.Z. Pankreonekroz i pankreatogennyi sepsis. Sostoyanie problemy. [Pancreatic necrosis and pancreatogenetic sepsis: State-of-the-art of the problem]. Annaly Khirurgii. 2003; 1: 12-19. [In Russ.]

14. Malakhova M.Ya. Endogennaya intoksikatsiya kak otrazhenie kompensatornoi perestroiki obmennykh protsessov v organizme. [Endogenous intoxication as a portrayal of the compensatory rearrangement of metabolic processes in the body]. Efferentnaya Terapiya. 2000; 6 (4): 3-14. [In Russ.]

15. Rantsev M.A., Sarapultsev P.A., Kuznetsov N.N., Chupakhin O.N., Sarapultsev A.P., Khodakov V.V., Sidorova L.P. Korrektsiya gemokoagulyatsionnykh narushenii pri eksperimentalnom pankreonekroze. [Correction of hemocoagulative disorders in experimental pancreatic necrosis]. Uralsky Meditsinsky Zhurnal. 2012; 1 (93): 26-29. [In Russ.]

16. De-Souza D.A., Greene L.J. Intestistinal permeability and systemic infections in critically ill patients: effect glutamine. Crit. Care Med. 2005; 33 (5): 1125-1135. PMID: 15891348

17. Brealey D., Brand M., Hargreaves I., Heales S., Land J., Smolenski R., Davies N.A., Cooper C.E., Singer M. Association between mitochondrial dysfunction and severity and outcome of septic shock. Lancet. 2002; 360 (9328): 219-223. http://dx.doi.org/10.1016/S0140-6736(02)09459-X. PMID: 12133657

Submited 20.04.13 